\title{
THE ROLE OF MUSEUMS IN THE DEVELOPMENT OF TOURISM
}

\author{
Umida A. Utanova
}

Associate Professor, Candidate Of Philosophical Sciences National Institute Of Art And Design Named After Kamoliddin Behzod Tashkent, Uzbekistan

\section{ABSTRACT}

The article analyzes the work being done in our country to increase the tourist potential of museums, cultural heritage sites, as well as the study of our history and cultural heritage sites inherited from our ancestors, its widespread promotion, the formation of advertising policy to attract tourists.

KEYWORDS: - Cultural heritage, museum, tourism, exhibit, advertising.

\section{INTRODUCTION}

Today's demand is to preserve the cultural heritage sites, which are the product of our rich history and the thinking of our ancestors, and to pass them to future generations, to increase the tourist potential of museums and cultural heritage sites. In our country, museums play an important role in restoring the historical memory of our people, raising our national values and traditions, as well as further developing the tourism potential of our country and increasing the interest of world tourism agencies and organizations in our country. In recent years, museums have become the pride, rich treasure and splendor of states and countries, as well as the busiest place for tourists.

\section{THE MAIN RESULTS AND FINDINGS}

Resolution of the President of the Republic of Uzbekistan Shavkat Mirziyoyev dated May 31,
2017 "On measures to further develop and improve the sphere of culture and art", Decree of May 26, 2020 "On measures to further enhance the role and influence of culture and art in society" is becoming an important guideline for further improvement of its activities. This document aims to organize the work of the museum at a higher level, to reconstruct its building and strengthen its material and technical base, to preserve the unique collection of invaluable artifacts, archeology, ethnography, fine and applied arts, to pass them on to future generations. Also, paragraph 3.2 of the Action Strategy for the five priority areas of development of the Republic of Uzbekistan for 2017-2021, proposed by the President of the Republic of Uzbekistan, states the importance of "Accelerated development of the service sector, increasing the role and share of services in GDP, radically changing the structure of services, primarily due to modern high-tech types of services". This requires a new approach to the activities of museums. Although the museum is a 
DOI: https://doi.org/10.37547/history-crjh-02-10-07

ISSN 2767-472X

(C)2021 Master Journals

\section{Crossref doi) 81 Google}

Accepted 22thOctober, 2021 \& Published 27thOctober, 2021

non-profit organization, the use of business practices in museums, ie marketing tools, is becoming a modern requirement. It is gratifying that in the Strategy of Action, the head of state pays attention to the priorities for the development of tourism. Because the development of tourism also has a positive impact on the development of social spheres such as museums. From the world experience we can see that museums also offer their products to the tourism market. Examples are the Louvre in Paris and the Prado in Spain. According to statistics, in 2019, the Louvre was visited by 9.6 million tourists and the Prado by 2.8 million. Museum tourism is also a unique activity of museums in the field of cultural tourism. In this regard, the state is doing a lot, in particular, to ensure the safety of tourists during the visit of President Islam Karimov to Bukhara region, the development of tourism, ecological, educational, ethnographic, gastronomic, sports, health, rural, industrial, business tourism and others. 18.5 billion sums will be spent on expanding cooperation with the nited Nations World Tourism Organization (UNWTO) and leading international and national tourism organizations, accelerated development of the tourism industry, construction and reconstruction of road transport and engineering and communication infrastructure. The State Committee for Tourism Development plans to implement 39 projects under the program to further increase the tourism potential of Bukhara region. There are 660 cultural heritage sites in Bukhara region. Most of them are archeological objects, monumental works of art, architectural monuments. The President stressed that these cultural heritage sites are the priceless wealth of our people, and it is our duty to preserve them and pass them on to future generations. He gave the necessary instructions to specialists and master builders on the preservation and repair of cultural heritage sites. During the visit, the President reviewed the project of the Bukhara State Museum of History. It was noted that 68.3 billion sums will be spent from the state budget for the construction of the museum, which will cover an area of 1.2 hectares. As well as it was highlighted that the unique exhibits kept in the Ark Fortress would be moved there. In particular, instructions were given to restore the ancient "Gijduvan Fortress", build an open-air museum, turn the village of Shirin in Vobkent district into an ethnotourism center, and establish the "Ibn Sino age" complex in Afshona village of Peshku district. An initiative to hold the Bukhara International Festival of Gold embroidery has been put forward.

The museum is an integral part of universal human history and is rich with globally significant phenomena. The museums study objectively the life of our ancient and close ancestors, their contribution to the development of the present, social development and the gradual development of various events of the past, when, where and in what state they took place, the emergence of humanity and its evolution, the process of evolutionary development.

The museum plays a very important role in the full realization of historical truth, in the writing of true history. Museums have been enriched over the years, a scientific, spiritual and enlightenment place that will pass on the invaluable heritage of our ancestors to future generations. It is known that in 1977, UNESCO designated May 18 as International Museum Day. This shows that the role of museums in the life of society and the importance of understanding the identity of peoples, the education of the younger generation is incomparable. By their nature, museums, first of all, focus all their attention only on the past, teach from it, draw conclusions, study the way of life of our ancestors, the 
DOI: https://doi.org/10.37547/history-crjh-02-10-07

ISSN 2767-472X

(C)2021 Master Journals

\section{Crossref doi) 81 Google}

Accepted 22thOctober, 2021 \& Published 27thOctober, 2021

material-cultural, spiritual-ideological values they created. Secondly, historical events and phenomena are studied in strict precision, on the basis of a periodic sequence. It is also determined whether historical events and happenings, documents and evidence are true and false, when, where, in what historical environment and circumstances they occurred. Finally, the exact causes and consequences of the events that took place, as well as their exact forms and status, are determined.

Thirdly, the causes and consequences of the state, development and decline of economic and social life in the past are studied, from which lessons and conclusions for the future are drawn. This will be guidelines for future generations.

Fourthly, it is multifaceted and diverse. He studies not only one aspect of the development and crises of society, but all aspects of society in an integral interdependence, as a whole. Taking into account these aspects, today a serious attention is paid to the comprehensive study of the preservation of historical masterpieces, the scientific study of the relics of the past, rare manuscripts. In particular, the Law "On Museums" and the Resolution of the Cabinet of Ministers of February 7, 2017 "On approval of a comprehensive program of measures to improve the activities and strengthen the material and technical base of state museums in 2017-2027" are aimed at raising the status of museums.

The Decree emphasizes the need to further improve the system of museums formed in the territory of Uzbekistan, to enhance their place in the spiritual and moral development of the people, to preserve the unique and rare exhibits reflecting the rich history of our people, the steps of our independence. It was noted that they should be widely used to study, enrich, bring to the world and promote, to strengthen in the minds of our people a sense of national pride, independence and devotion to the Motherland. It was noted that it is necessary to provide museums with highly qualified specialists in accordance with modern requirements, strengthen the material and technical base and create the necessary conditions for the application of the best practices of world museology. Accordingly, there are significant changes in the structure of museums - new departments are being created, the main purpose of which is the provision of information. In order to increase the tourist potential of museums and cultural heritage sites, measures have been developed for the preparation of information materials in foreign languages, the widespread introduction of information and communication technologies in the industry. Traditional museum vocabulary (language) is enriched with new concepts such as market, marketing, management, advertising. It is also important to study the objects of cultural heritage that have come down to us from our own history and ancestors, to promote it widely, to form an advertising policy in attracting tourists. Establishing regular relationships with regular customers is of paramount importance. Museums are realizing that they need to not only work with visiting tourists, but also have permanent partners among the local population. The establishment of museum marketing activities in the museum is a modern requirement. It takes into account the interests of all active participants - museum researchers, guardians, sponsors, entrepreneurs. As a result, new visitors will be attracted to the museum. Advertising is one of the means of communication. Communication is not just an integral chain of events aimed at attracting the attention of the general public; the communicative model requires mandatory feedback between key participants. Advertising helps in managing the flow of information, 
DOI: https://doi.org/10.37547/history-crjh-02-10-07

ISSN 2767-472X

(C)2021 Master Journals

\section{Crossref doi) 81 Google}

Accepted 22thOctober, 2021 \& Published 27thOctober, 2021

communicating with the public. The Law of the Republic of Uzbekistan "On Advertising" defines advertising as follows: "Advertising - special information about legal entities or individuals, products, including trademarks, service marks and technologies, in any form and by any means in accordance with the legislation for the purpose of direct or indirect profit (income)." The museum, which is interested in accelerating domestic and international communications, can use advertising to disseminate extensive information about its and its partners' activities. Information transmitted through advertising can have both positive and negative effects on a museum's image. Managing one's own information space becomes a necessity, the internationalization of museum work and the attraction of new participants require a partial break with old views about the museum and linking museum practice to economic theory of management. The formation of an advertising policy in the activities of the museum aims to attract as many visitors as possible. While trying to expand their audience, museums should try to strengthen the reputation of their institution and build relationships.

Today, museums use the following types of advertising policies to promote their exhibitions or collections:

* Collaboration with the media, providing daily information on non-sensational events;

* organization of special seminars, preparation of press releases with useful information in the process of organization;

* preparation of media, combining several different materials with photos attached;

* it is also necessary to provide information about the history and value of a particular exhibit during the radio broadcasting (learn to give information briefly, succinctly). Usually the time to express the best news does not exceed 2 minutes, 30-40 seconds is the most optimal. Any message, even the smallest one, should carry dynamism and informativeness so that a certain level of publicity is provided for the museum.

* Outdoor advertising tools: Troll - the use of two-sided advertising construction (It is placed horizontally on vertical bases on the road. It is armed with interior lighting, which gives it a great effect in the dark. Lighting is mainly done in fluorescent lamps.) Citylight is a panel on the sidewalk. (It can be located on the sidewalk, in its corner, on the edge. This design has a lighting feature. This ensures that the evening lighting effect has a great impact power.)

Advertising - information about the work of the museum should not look like a plaque. In general, this task can be performed by all the products of the museum - catalogs, souvenirs, videos, products purchased from museum kiosks, and even a cellophane bag in which they are placed. As you walk outside the museum wall, the vouchers that serve as this sign remind your owner that you have visited the museum, and that those around you know about the museum's existence. In its pursuit of greater economic efficiency, the museum has abandoned old stereotypes and become an alternative, open, and useful institution to society.

\section{Conclusion}

Therefore, the following changes can be made in the field of museums:

- to acquaint citizens and tourists of our country with the relics of our history kept in museums of our country, as well as in foreign museums. Forming a spirit of respect for universal values, our vast and rich national and cultural heritage in the minds of the people through the unique exhibits in our museums; 
DOI: https://doi.org/10.37547/history-crjh-02-10-07

ISSN 2767-472X

(C)2021 Master Journals

\section{Crossref doi) 81 Google}

Accepted 22thOctober, 2021 \& Published 27thOctober, 2021

- Development of international relations, mutually beneficial cooperation in the field of museology, introduction of the rich history and current achievements of our country to the world community through a wide range of exhibitions in Uzbekistan and abroad;

- Achieve worldwide promotion of unique exhibits stored in museums. These, in turn, will allow us to develop our country, its economic growth, be proud of our rich history, preserve our identity, and carry out great tasks such as passing on a great legacy to future generations.

\section{REFERENCES}

1. Abdullakhodjaev G. T. Protection Of Moral And Material Rights Of Copyright Subjects //The American Journal of Social Science and Education Innovations. - 2021. - T. 3. №. 03. - С. 73-80.

2. Алимов H. Ю. COPYRIGHT PROTECTION THROUGH BLOCKCHAIN //Актуальные научные исследования в современном мире. - 2019. - №. 5-6. - С. 26-28.

3. Alimov N. Y. Architectural project-As an object of copyright //ASIAN JOURNAL OF MULTIDIMENSIONAL RESEARCH. - 2021. - T. 10. - №. 4. - C. 914-918.

4. AN Yunusovich. Occasional Use Of Anothers Work //The American Journal of Social Science and Education Innovations 3 (05), 47-52

5. Маруфбаев Б. Ш. ЭТНОКУЛЬТУРНОЕ МЫШЛЕНИЕ-КРИТЕРИЙ НАЦИОНАЛЬНО-ДУХОВНОГО РАЗВИТИЯ //Актуальные научные исследования в современном мире. - 2018. - №. 2-4. - С. 60-64.
6. Sherbekovich M. B. Contemporary Art Is A Factor For Developing Democratic Thinking, Forming A Strong Citizen Position //The American Journal of Social Science and Education Innovations. - 2020. - T. 2. - №. 11. - C. 557-561.

7. Машарипова Г. ЁШЛАРДА ҒОЯВИЙ ИММУНИТЕТНИ РИВОЖЛАНТИРИШДА МАЪНАВИЙ ОМИЛЛАРНИНГ ЎРНИ //Камолиддин Бехзод номидаги Миллий рассомлик ва дизайн институти АХБОРОТНОМАСИ илмийамалий журнали. - 2021. - Т. 5. - №. 01.

8. Utanova, U. A. (2020). FOLK CULTURE IS A SOCIO-HISTORICAL PHENOMENON. International Engineering Journal For Research \& Development, 5(9), 5-5.

9. Утанова, У. А. (2014). Общечеловеческое и национальное в народной культуре. In Сборники конференций НИЦ Социосфера (No. 38, pp. 91-95). Vedecko vydavatelske centrum Sociosfera-CZ sro.

10. Utanova, U. A. (2019). ScientificallyPhilosophical Analysis of Cultural And Spiritual Heritage. International Journal on Integrated Education, 2(1), 53-55.

11. Сабирова, Р. Г., \& Утанова, У. (2016). Народная культура»: понятие, сущность, социально-философский анализ. ББК 72я43 C, 56, 183.

12. Utanova U. A. et al. ScientificallyPhilosophical Analysis of Cultural And Spiritual Heritage //International Journal on Integrated Education. - 2019. - T. 2. №. 1. - C. 53-55.

13. Fayazova F. Methodology of Vocational Training And Pedagogical Practice As The Main Factors In The Preparation of A Future Teacher of Vocational Training //The American Journal of Social Science 
CURRENT RESEARCH JOURNAL OF HISTORY 2(10): 27-32, October 2021

DOI: https://doi.org/10.37547/history-crjh-02-10-07

ISSN 2767-472X

(C)2021 Master Journals

Crossref dof 81 Google

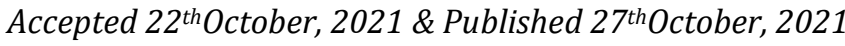

and Education Innovations. - 2021. - T. 3. №. 03. - C. 27-31.

14. Утанова У.A. INTERNETNING INSON AXLOQIY VA ESTETIK DUNYOSIGA TA'SIRI

//

15. СБОРНИК ТРУДОВ международной научно-теоретической конференции на тему: «Куатбековские чтения-1: Уроки Независимости», посвященной 30летию Независимости Республики Казахстан - Шымкент, 2021 - С 188-190 